Research Article

\title{
Investigation of Halal Certification and Country of Origin of FMCG Products
}

\author{
Anum Memon ${ }^{1,}$, Muhammad Aslam Memon ${ }^{2}$, Adnan Pitafi ${ }^{1}$ and Pireh Panhwar ${ }^{1}$ \\ ${ }^{1}$ Mehran University of Engineering and Technology, Jamshoro, Sindh, Pakistan \\ anummemon2017@gmail.com; adnan.pitafi@faculty.muet.edu.pk \\ ${ }^{2}$ Gas turbine power station (GTPS) (WAPDA), Kotri, Sindh, Pakistan \\ pirehpanhwer.123@gmail.com \\ *Correspondance: anummemon2017@gmail.com
}

Received: 25 $5^{\text {th }}$ July 2019; Accepted: $18^{\text {th }}$ December 2019; Published: $1^{\text {st }}$ February 2020

Abstract: This paper aims to investigate various products of key distributors in Hyderabad market accordance with halal Certification and country of origin. The FMCG products are surveyed. As the demand of these products are increasing day by day. With the rapid increase of FMCG sector, Pakistan Being an Islamic country Muslims are at ease as they believe that whatever the product that is available in market is halal. Not give a second thought of country of origin. The research is performed on a survey based study to investigate the FMCG products. In that product are categorized into two categories that are food and non-food products. The survey is conducted in Hyderabad of different super markets that include Dawood super mart, Max bachat, The Grocers, Baig mart, Hamid super store and many other. In this research Food Products that are surveyed includes beverages, Dairy Products, baked Products and snacks. And Non-food products that are surveyed include Cosmetics, Toiletries, Cleaning Product and Fragrance products. Present study found that there is very less products in market are halal certified. It is an alarming time for Pakistan as it is an Islamic country there is no halal certification body that can certify the products. In food category 62 products of Beverages were surveyed out of which only $24 \%$ are halal certified, 37 dairy Products were surveyed out of which only $24.3 \%$ are halal certified , 30 snack food were surveyed out of which only $30 \%$ are halal certified and 84 baked products were surveyed out of which only $50 \%$ are halal certified. In Nonfood category 69 Toiletries Products were surveyed out of which only $13 \%$ are halal certified, 26 Cleaning products out of which $0 \%$ are halal certified, 62 Cosmetic products out of which $0 \%$ are halal certified, 63 Fragrance products out of which $0 \%$ are halal certified. The total number of food products were surveyed was 213 . Out of them only 35.2\% were halal Certified. The total number of Non-food Products were surveyed was 220 Products. Out of them only $4.09 \%$ were halal certified. Pakistan has no regulatory body who can checked the products that are available in market, are Halal certified or not. This research is one of the few studies in context of Pakistan which is investigating the FMCG products accordance with halal certification and country of Origin. The study also provided new findings of Pakistani Market that there are very less products which are halal certified. The result of the study is quite different with other halal studies.

Keywords: Halal awareness; Halal certification; Halal products; FMCG products; Halal business

\section{Introduction}

The Muslim Population is the $2^{\text {nd }}$ most rising population in the world and with the rising Population and conversion of religion to Islam, the need of Halal consumptions has been observed on the huge scale

Anum Memon, Muhammad Aslam Memon, Adnan Pitafi and Pireh Panhwar, "Investigation of Halal Certification and Country of Origin of FMCG Products", Annals of Contemporary Developments in Management \& HR (ACDMHR), Print ISSN: 2632-7686, Online ISSN: 2632-7694, pp. 22-30, Vol. 2, No. 1, $1^{\text {st }}$ February 2020, Published by International Association of Educators and Researchers (IAER), DOI: 10.33166/ACDMHR.2020.01.003, Available: http://acdmhr.theiaer.org/archive/v2/v2n1/p3.html. 
throughout the world. The need of halal consumption is the basic demand of every Muslim so that he or she may satisfy the hunger.

Halal in all term implies allowed, permitted, approved, endorsed, authorized, legal and lawful. The word food for Muslims or consumption ensured Halal or having comparative implications can be characterize as pursues: A portion of the ground needs of Halal food resemble it is free from any sort or substance that is extracted from haram or prohibited methods or conversely of the Islamic laws. The particular substance or product is clear of being filth in accordance to the Sharia. (S Ahmed, T Asif, Z Rafi, 2017).

The demand of halal market is expected to be around USD\$790 billion in 2020 that are composed of beverages, food items, pharmaceutical products and healthcare. Although the demand can be only supplied approximately $20 \%$ or USD $\$ 136$ billion. So the gap between both demand and supply becomes the most beneficial advantage for the Halal producers to fill the gap in especially in halal international markets (Mustapa, 2015).

It is estimated that in 2030 Muslim population will increase by 58 million, which will increase the demand of halal food in market. According to the given statistic on Google, it says that over $53 \%$ of the total population of Africa represents Islam which is more than any other continent of the world.

Halal dietary laws build up which food are permitted or prohibited (for example haram) for Muslims. These laws are set up in the Quran and the Hadith, and are portrayed and interpreted by Muslim researchers and scholars (Riaz and Chaudry, 2004). Halal basically required a supply chain network, as the supply chain and value chain should be aligned together (Christopher, 1998; van Amstel and van Goor,2001;van Assenetal,2010) so that to fulfil the guarantee of halal to the consumer: the food items they consume is the true manifestation of Islamic laws (WorldHalalForum,2009).

\section{Literature Review}

\subsection{Halal Concept in Quran and Hadith}

\subsubsection{In Quran}

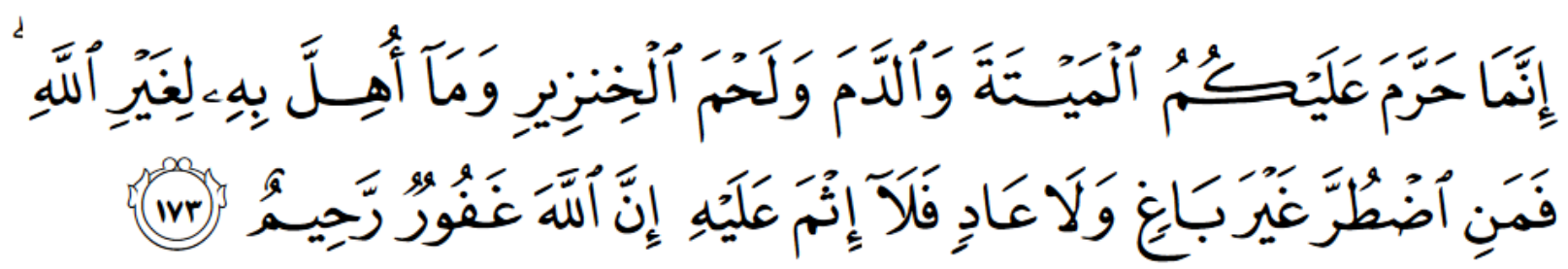

\section{Meaning}

He has only prohibited for you carrion, blood, the flesh of the swine, and that upon which a name of someone other than Allah' has been invoked. Then, whoever is compelled by necessity, neither seeking pleasure nor transgressing, there is no sin on him. Verily, Allah is Most-Forgiving, Very-Merciful.

\subsubsection{In Hadith}

Reported by Bukhari, Muslim, Abu Daud, Ibn Majah and Darimi as follows

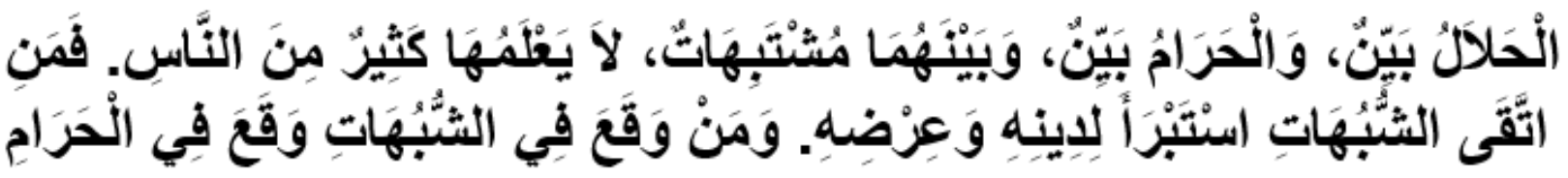

\section{Meaning}

What is halal is clear. And what is haram is also clear. And in between those two is a dubious area in which many people do not know about. So whoever distanced himself from it, he has acquitted himself (from blame). And those who fall into it, he has fallen into a state of Haram. 


\subsection{FMCG}

Will Kenton (2019) Fast-moving consumer goods are products that sell quickly at relatively low cost. These goods are also called consumer packaged goods. FMCGs have a short shelf life because of high consumer demand like beverages, confections, dairy products, and baked goods. These goods are purchased frequently, are consumed rapidly, are priced low, and are sold in large quantities.

\subsection{Current Situation of FMCG Sector in Pakistan}

Surging demand for fast moving consumer goods (FMCG) in Pakistan is attracting hundreds of millions of dollars of new investments. Expanding middle class, particularly millennials with rising disposable incomes, is demanding branded and packaged consumer goods ranging from personal and baby care items to food and beverage products (Riaz Haq, 2018). Rapid growth in sales of consumer products and services is driving other sectors, including retail, e-commerce, paper and packaging, advertising, media, sports and entertainment. It estimates Pakistan's current retail market size at $\$ 152$ billion.

\subsection{FMCG Sector Growth}

It is forecast to expand $8.2 \%$ a year through $2016-2021$ as average disposable income has doubled since 2010, according to research group Euromonitor International as reported by Bloomberg News. As majority of the products available in the market place are having the Halal logo but without any authentic organization endorsing it. It is a big alarming to note that Pakistan being an Islamic country does not have its own Halal Certification body and majority of the products are either simply labelled as Halal or have endorsing organizations of South Africa, Indonesia, Malaysia and USA.

\subsection{Halal Supply Chain Management}

Zulfakar et al. (2014) "The process of dealing with Halal meals products from distinctive points of providers to various points of buyers/ customers, which involved diverse parties, who are positioned at unique locations, who may additionally on the identical time, involved with managing non-Halal food products, with the purpose of pleasing the desires and necessities of each (Halal and non-Halal) customers."

\subsection{Difference between Conventional SCM and Halal SCM:}

The difference between the conventional supply chain and halal supply chain can be elaborated through various perspective. Some of the major aspects that arr worthy to highlight are as follows:

Table 1. SCM V/S Halal SCM

\begin{tabular}{|c|c|c|}
\hline \multicolumn{3}{|c|}{ Comparison } \\
\hline Element & Conventional Supply Chain & Halal Supply Chain \\
\hline Definition & $\begin{array}{l}\text { Supply chain management is the network that } \\
\text { includes different activities through its planning, } \\
\text { implementing and controlling from its raw material } \\
\text { to the finished goods. }\end{array}$ & $\begin{array}{l}\text { Halal supply chain is said to be halal when all the processes } \\
\text { which includes from its raw material to its final product are } \\
\text { kept according to Islamic laws. }\end{array}$ \\
\hline Objective & To maximize the profit with minimize the cost & It assure the halal integrity of halal products for consumers \\
\hline $\begin{array}{l}\text { Cross } \\
\text { contamination } \\
\text { occurrence }\end{array}$ & There is the chance of cross contamination exist & It is assure no contamination exist \\
\hline Segregation needs & $\begin{array}{l}\text { There is the chance for no separation among various } \\
\text { products }\end{array}$ & Both halal and non halal products should be separated \\
\hline
\end{tabular}

Source: Mohd Bahrudin et al. (2011) 


\subsection{Halal Certification}

Halal certified products is the essential reason for the Muslim consumers to buy halal products on daily basis. It is because the Halal certified products gives a guarantee to the Muslim that product are halal accordance with Islamic Sharia law. Accordance to Abdul (2008) and Riaz (2004), halal certification, like the halal Brand logo of Compliance, that is issued by the authorized and reputable halal certification bodies, indicates that the product have sufficiently met Islamic dietary. Similarly halal certification is not only applied on the products that is used by the consumers but also it applied on the cafes or restaurants, dinning outlets as Muslims will look for halal certified places to consume. It suggests that Halal certification does not only apply to the groceries and meats but it applied on the food service providers as well. However, Riaz (2004) stated that halal logo or certificates must be authorized and issued by a trustworthy Islamic organization in order to prevent from any fake, fraud, and misleading logo or certificates.

\subsubsection{Halal Label}

The majority of Muslims have greater interest for the halal meals. The studies performed via (Bonne, 2008) Highlighted that spiritual values have an impact on customer intentions of consuming meat and its by-product products. Muslims clients worry to consume the by-product merchandise of meat that use packaging derived from non-halal materials. The study by Marzuki (2012) stated the importance about that was the non-halal substances did not be contaminated raw materials. The Study recommended the need to be guaranteed for the Muslim consumers to consume halal products. It only be done when the whole supply chain network should be accordance with Islamic Sharia as well as halal certification is the basic need for it. Due to the halal certification of the products, the manufacturers get much benefits from it and also they capture more market share. The imported frozen ingredients require the lifestyles of the halal certificate of meals derived from animals and of derivatives such as goat and duck meat, sausages and nuggets, as well as milk and its by-product products including cheese, skim milk, whey, and powder (halalmui.org).

\subsubsection{Country of Origin}

The research of Ozretic (2007) referred to in Rezvani (2012) stated that the country of origin is the source of product assessment for purchasers. a few instances are caused by an acceleration of globalization, a rapid go with the flow of records, and also the diversity of products in an emerging market complicated. Country of origin beginning as an arena of company Competition occurs in the contexts of global market growth. Lee (2009) stated that the country of origin is the first sign for the customers because of the limited information and about the knowledge of the product. As a result, purchaser evaluate and check the information that is available on the product like it is derived from a particular country, and label as "made in" as evaluation criteria (Ha, 2012). Consumers evaluated the products which are manufactured in developed countries like japan, Germany, America are considered as high quality products, In the same way those products which are made in developing countries are assumed by the consumers as low quality products (Abedniya, 2011). Countries of origin with negative consumer perceptions will affect purchase behavior and could even result in the boycott of the products. Such as the case of Danish cartoons, which led the Muslim world to boycott products from Denmark (Alserhan, 2010).

\subsection{Halal distribution}

Halal distribution includes halal packaging and halal packing containers. Packaging characteristics consisting of materials have an impact at the halalness of the product. Among problems which have been raised within packaging are halal certification on the packaging, halal techniques of product handling and halal traceability of the packaging (Ab Talib, M.S., \& Mohd Johan, M.R., 2012). In the context of halal, packaging involves positive elements which include halal certification or the halal logo, a listing of substances and the product's beginning (Rezai et all., 2012). The other basic feature of packaging in logistics 
is to incorporate and protect the goods at some stage in delivery and distribution. it is also practiced to defend people managing the products from risks which include chemical substances, beverages, or loose merchandise. inside the context of halal, packaging will guard goods from any cross- infection among halal and non-halal substances. All through transportation and distribution, packaging is used to segregate halal and non-halal merchandise either by the usage of separate companies or separate booths in a equal carrier (Ab Talib, M.S \& Mohd Johan, M.R.,2012).

\subsection{Halal Market}

Halal marketplace is huge and expensive. The rapidly growing enterprise is well worth greater than USD500 billion these days. The marketplace trend of Halal merchandise is similar with different types of product and expected to grow particularly within the close to future. Principal reasons contributing to this marketplace growth are big agricultural production by exporting nations and extra shopping power amongst Muslim purchasers within the importing countries. Besides that, the current growing fashion of human beings choosing healthier way of life specifically with regards to the meals that they fed on has put Halal meals products, already known of its clean and unharmful ingredients, in the spotlight. consequently, Halal food has the potential to a wider market of world population, not only for the Muslim consumers.

Halal product is likewise being sought by means of the non-Muslim purchasers. Halal food products aren't exclusively for the Muslim consumers. With the contemporary trend of those who are actively seeking for cleaner, safer and more healthy meals for his or her healthy lifestyle, Halal meals products offer this group of purchasers a new choice that is loose from harmful elements as it is the basic principles in the production of Halal food products. One of the thrilling statistics on Halal industry these days is that almost all primary exporters of Halal products came from non-Muslim nations (Raja Adam, 2006 as quoted. for example, countries together with Argentina, Australia, Brazil, Canada, China, India, New Zealand, the UK and the USA are the most important producers and exporters of Halal meat in the global.

\subsection{Research Gap}

The main focus of this study is to conduct in the context of Pakistan is to investigate the Pakistani market accordance with halal certification. Pakistan is an Islamic Country, People only think about halal concept regarding meat but it carry both food and Non-Food products. In this research FMCG products of key distributors are surveyed according to halal certification and Country of Origin, so that to analyze the current status of the Pakistani Market.

\section{Research Methodology}

\subsection{Research Approach and Nature}

This research employs a quantitative approach which used a survey based in order to investigate the halal certification on the FMCG products. And the Nature of the research was exploratory. In this study the current status of Pakistani market has been investigated according to the halal certification and country if origin.

\subsection{Sampling Technique and Sample Size}

As day by day the demand of FMCG products are increasing. Survey was conducted to collect data from various FMCG products of key distributors that are available in supermarkets, super mart and many other. The survey was conducted to investigate the FMCG products according to the Halal Certification and Country of Origin. This study helps to analyze the current status of Pakistani market. This research has been conducted in Hyderabad city. Different supermarkets are be surveyed. The products that were 
surveyed which are available in market. Primary data is conducted by analyzing FMCG product, they were well investigated either halal certified or not and their country of origin, products were accessed from different grocery store in Hyderabad city. Secondary data was collected through literature survey, authentic website, reports, Thesis.

\subsection{Data Collection Method and Analysis}

Data is collected through survey and Observation. The survey was conducted in different supermarkets of Hyderabad city. The data are be analyzed according to the halal certification, as how much products that are available in Hyderabad market. Products were classified into Food items and Nonfood items. The total number of Food products were surveyed was 213 products. And the total number of Non-Food Products were surveyed was 220 products.

Table 2. Product Categories

\begin{tabular}{|c|c|c|c|}
\hline \multicolumn{2}{|r|}{ Food Products } & \multicolumn{2}{|c|}{ Non Food Product } \\
\hline \multicolumn{2}{|r|}{ Beverages } & \multicolumn{2}{|r|}{ Toiletries } \\
\hline Sub category & No of items surveyed & Sub category & No of items surveyed \\
\hline Tea & 15 & Shampoo & 12 \\
\hline Bottled water & 7 & Face wash & 8 \\
\hline Soft drinks & 17 & Soap & 18 \\
\hline Juices & 10 & Toothpaste & 8 \\
\hline Coffee & 2 & Hand Wash & 10 \\
\hline Sharbat & 11 & Total & 69 \\
\hline Total & 62 & & \\
\hline \multicolumn{2}{|r|}{ Dairy Products } & \multicolumn{2}{|c|}{ Cleaning Product } \\
\hline Sub category & No of items surveyed & Sub category & No of items surveyed \\
\hline Milk & 13 & Detergent & 10 \\
\hline Cheese & 14 & Dishwasher soap & 6 \\
\hline Yogurt & 3 & Liquid Cleaner & 10 \\
\hline Butter & 7 & Total & 26 \\
\hline Total & 37 & & \\
\hline \multicolumn{2}{|c|}{ Snack Food } & \multicolumn{2}{|r|}{ Cosmetics } \\
\hline Sub category & No of items surveyed & Sub category & No of items surveyed \\
\hline Chips \& Nimko & 30 & Foundations & 13 \\
\hline \multicolumn{2}{|l|}{ Total } & Lipsticks & 13 \\
\hline & & Compact powders & 13 \\
\hline & & Eye Pallets & 15 \\
\hline & & Primer & 8 \\
\hline & & Total & 62 \\
\hline \multicolumn{2}{|c|}{ Baked Products } & \multicolumn{2}{|c|}{ Fragrance } \\
\hline Sub category & No of items surveyed & Sub category & No of items surveyed \\
\hline Biscuits & 40 & Perfumes & 35 \\
\hline Bread \& Buns & 15 & Body spray & 13 \\
\hline Cake & 17 & Deodorants & 15 \\
\hline Pizza & 12 & Total & 63 \\
\hline Total & 84 & \multirow{2}{*}{\multicolumn{2}{|c|}{ Total Non-Food Product $=220$}} \\
\hline & Food Products $=213$ & & \\
\hline
\end{tabular}

*The Total number Products surveyed were 433. 


\section{Results and Discussion}

\subsection{Food Products survey results regarding Halal certification}

\subsubsection{Beverages Products}

Total Beverages Products=15/62x100=24.1\% (In beverages product $24.1 \%$ products are halal certified.) In food Product, there are 4 different categories were be surveyed. In that 1 st one is the beverages that is consists of different items that includes Tea, Bottled water, Soft-Drinks, Juices, Coffee and Sharbat. The total number of beverages products were be surveyed is 62 . Out of them only $24.1 \%$ were halal certified.

\subsubsection{Dairy Products}

Total Dairy Products=9/37x100=24.3\% (In Dairy Products 24.3\% products are halal certified.) In food Product, 2nd category were be surveyed is the Dairy Products. The dairy products were consists of different items that includes Milk, Cheese, Yogurt and Butter. The total number of Dairy Products were be surveyed is 37 . Out of them only $24.3 \%$ were halal certified.

\subsubsection{Snack Food}

Total Snack Food=9/30x100=30\% (In Snack Food 30\% products are halal certified.) In food Product, 3rd category were be surveyed is the Snack Food. The Snack Food were consists of different items that includes Chips \& Nimko. The total number of Snack Food were be surveyed is 30 . Out of them only $30 \%$ were halal certified.

\subsubsection{Backed Products}

Total Backed Products $=42 / 84 \times 100=50 \%$ (In Backed Products 50\% products are halal certified.) In food Product, 4th category were be surveyed is the Backed Products. The Backed Products were consists of different items that includes Biscuits, Bread \& Buns, Cake and Pizza. The total number of Backed Products were be surveyed is 84 . Out of them only $50 \%$ were halal certified.

The food Product were be surveyed. In Food Products that were consists of different items that includes Beverages Products, Dairy Products, Snack Food and Backed Products. The total number of Food Products were be surveyed is 213 Products. Out of them only $35.2 \%$ were halal certified.

\subsection{Non Food Products survey results regarding Halal certification}

\subsubsection{Toiletries Products}

Total Toiletries Products=9/69x100=13\% (In Toiletries Products 13\% products are halal certified.)

In Non-food Product, there are 4 different categories were be surveyed. In that 1st one is the Toiletries that is consists of different items that includes Shampoo, Face wash, Soap, Toothpaste and Hand Wash. The total number of Toiletries products were be surveyed is 69 . Out of them only $13 \%$ were halal certified.

\subsubsection{Cleaning products}

In Non-food Product, $2^{\text {nd }}$ category were be surveyed is the Cleaning Products that is consists of different items that includes. The total number of Cleaning Products were be surveyed is 26 . Out of them no were halal certified.

\subsubsection{Cosmetics products}

In Non-food Product, $3^{\text {rd }}$ category were be surveyed is the Cosmetics Products that is consists of different items that includes. The total number of Cosmetics Products were be surveyed is 62 . Out of them no were halal certified.

\subsubsection{Fragrance products}

In Non-food Product, $4^{\text {th }}$ category were be surveyed is the Fragrance Products that is consists of different items that includes. The total number of Fragrance Products were be surveyed is 63. Out of them no were halal certified. 


\subsubsection{Non Food Product}

The Non-food Product were be surveyed. In Non-Food Products that were consists of different items that includes Toiletries Products, Cleaning Products, Cosmetics Products and Fragrance Products. The total number of Non-Food Products were be surveyed is 220 Products. Out of them only $4.09 \%$ were halal certified.

\section{Conclusion and Limitations}

The study found that there is very less products are halal certified. As Pakistan is an Islamic country but there is very less products are halal certified in marketplace. This study was conducted to check current status of the Pakistani market. In that 2 categories of the products were surveyed. $1^{\text {st }}$ one is the Food Products. The total number of food products were surveyed was 213 . Out of them only $35.2 \%$ were halal Certified. The $2^{\text {nd }}$ one is the Non-Food Products. The total number of Non-food Products were surveyed is 220 Products. Out of them only $4.09 \%$ were halal certified. Pakistan has no regulatory body who can checked the products that are available in market, are Halal certified or not. It is a big alarming tine for Pakistan to take some actions for that. This study is one of the few studies in the context of Pakistan current status of the market.

\section{References}

Tieman, M. (2013). Establishing the principles in halal logistics. Journal of Emerging Economies and Islamic Research, 1(1), $1-13$.

Afsar, B., Umrani, W. A., \& Khan, A. (2019). The impact of perceived calling on work outcomes in a nursing context: The role of career commitment and living one's calling. Journal of Applied Biobehavioral Research, 24(1), e12154.

Zulfakar, M. H., Jie, F., \& Chan, C. (2012, June). Halal food supply chain integrity: from a literature review to a conceptual framework. In 10th ANZAM Operations, Supply Chain and Services Management Symposium (Vol. 1, No. 61, p. 4).

Mentzer, J. T., DeWitt, W., Keebler, J. S., Min, S., Nix, N. W., Smith, C. D., \& Zacharia, Z. G. (2001). Defining supply chain management. Journal of Business logistics, 22(2), 1-25.

Larson, P. D., \& Rogers, D. S. (1998). Supply chain management: definition, growth and approaches. Journal of Marketing Theory and Practice, 6(4), 1-5.

Ahmed, S., Asif, T., \& Rafi, Z. Application of Halaal Supply Chain in Food/Pharmaceutical Industry - In Depth Interviews.

Zulfakar, M. H., Jie, F., \& Chan, C. (2012, June). Halal food supply chain integrity: from a literature review to a conceptual framework. In 10th ANZAM Operations, Supply Chain and Services Management Symposium (Vol. 1, No. 61, p. 4).

Omar, E. N., \& Jaafar, H. S. (2011, September). Halal supply chain in the food industry-A conceptual model. In 2011 IEEE Symposium on Business, Engineering and Industrial Applications (ISBEIA) (pp. 384-389). IEEE.

Muhamed, A. A., Ab Rahman, M. N., \& Zain, C. R. C. M. (2019). Drivers for the Willingness of Small and Medium Enterprise in Implementing Halal Supply Chain Management. International Journal of Engineering \& Technology, 8(1.2), 146-152.

Rasi, R. Z., Masrom, N. R., Omar, S. S., Ahmad, M. F., \& Sham, R. (2017). Designing Halal Supply Chain: Malaysia's Halal Industry Scenarios. In MATEC Web of Conferences (Vol. 135). EDP Sciences.

Saifudin, A. M., Zainuddin, N., Elias, E. M., \& Fatehah, S. N. (2018). Reviewing the Contributors towards the Performance of the New Islamic Supply Chain Model. Int. J Sup. Chain. Mgt Vol, 7(4), 151.

Nasution, M. D. T. P., \& Rossanty, Y. (2018). Country of origin as a moderator of halal label and purchase behaviour. Journal of Business and Retail Management Research, 12(2).

Zulfakar, M. H., Anuar, M. M., \& Ab Talib, M. S. (2014). Conceptual framework on halal food supply chain integrity enhancement. Procedia-Social and Behavioral Sciences, 121, 58-67.

Yahya, H. (2006). "The Holy Quran." Available: http://www.harunyahya.com/Quran_translati on/Quran_translation_index.php. 
Metwalley, H. Sahi Bukhari Hadees Collection. http://www.pakalumni.com/profiles/blogs/fast-moving-consumergoods-fmcg-boom-in-pakistan-s-152-billion-re

(C) 2020 by the author(s). Published by Annals of Contemporary Developments in Management \& HR (ACDMHR), under the terms and conditions of the Creative Commons Attribution (CC BY)

license which can be accessed at http://creativecommons.org/licenses/by/4.0. 